Louisiana State University

LSU Digital Commons

Faculty Publications

Department of Geology and Geophysics

$1-1-2011$

\title{
Did intense volcanism trigger the first Late Ordovician icehouse?: Comment
}

Achim D. Herrmann

School of Earth and Space Exploration

Stephen A. Leslie

James Madison University

Kenneth G. MacLeod

University of Missouri

Follow this and additional works at: https://digitalcommons.Isu.edu/geo_pubs

\section{Recommended Citation}

Herrmann, A., Leslie, S., \& MacLeod, K. (2011). Did intense volcanism trigger the first Late Ordovician icehouse?: Comment. Geology, 39 (5) https://doi.org/10.1130/G31758C.1

This Article is brought to you for free and open access by the Department of Geology and Geophysics at LSU Digital Commons. It has been accepted for inclusion in Faculty Publications by an authorized administrator of LSU Digital Commons. For more information, please contact ir@lsu.edu. 


\section{Did intense volcanism trigger the first Late Ordovician icehouse?: COMMENT}

\section{COMMENT: doi:10.1130/G31758C.1}

Achim D. Herrmann', Stephen A. Leslie ${ }^{2}$, and Kenneth G. MacLeod ${ }^{3}$ ${ }^{1}$ Barrett, the Honors College, and School of Earth and Space Exploration, Arizona State University, Sage Hall 170, Tempe, Arizona 85287, USA

${ }^{2}$ Department of Geology \& Environmental Science, James Madison University, Harrisonburg, Virginia 22807, USA

${ }^{3}$ Department of Geological Sciences, University of Missouri, Columbia, Missouri 6521, USA

Details of the climate evolution during the Middle and Late Ordovician are increasingly debated, with implications for understanding both greenhouse-icehouse transitions and the Late Ordovician mass extinction. We applaud Buggisch et al. (2010) for attempting to distinguish among different alternatives of climate states during this time period using temperature estimates from the relatively robust phosphate-oxygen paleothermometer as recorded in conodonts and fish teeth. However, we think they have made an error in plotting the position of their Minnesota samples relative to the Deicke K-bentonite (DKb). This error does not diminish the importance of their data, but it does remove support for their conclusion that the volcanic eruption that led to the deposition of the DKb initiated a short-term cooling event of at least $6{ }^{\circ} \mathrm{C}$, and possibly a first short-term glacial episode during the Late Ordovician.

Buggisch et al. plotted none of their samples below the DKb (their figures 1 and 2). A critical review of the original stratigraphic description of the location of the conodont samples for the Minnesota section (Thompson, 1959; Webers, 1966), as described in their supplementary data set (Table DR1 in GSA Data Repository item 2010087), indicates that eight samples predate the Deicke eruption. This includes the sample with the highest $\delta^{18} \mathrm{O}$ value (Fig. 1). Samples with sample letters "Pl" (see Table DR1 in Buggisch et al.'s Data Repository) are from the Cummingsville Annex Section (CAS), which has been described in detail by several researchers (Sloan, 1987; Thompson, 1959; Webers, 1966). Specifically, we argue that samples P110/11, Pl12, Pl13, both of the Pl14 samples, P116, and Pl16A are from below the DKb, with sample P116 (described as collected from a shale that is associated with a bentonite [Webers, 1966]) occurring directly below the $\mathrm{DKb}$, because

1. The bentonite has been identified and described as the $\mathrm{DKb}$ (Sloan, 1987).

2. A shale horizon is a common occurrence in the upper Midwest United States below the DKb (e.g., Weiss, 1955) including the CAS, where a shale interval is present immediately underneath the DKb but not above it (Thompson, 1959).

3. Samples Pl16 and below contain Polyplacognathus, which in Minnesota only occurs in significant numbers below the DKb (Leslie, 2000, 2009; Sloan, 1987; Webers, 1966; and our own observations). Sample Pl14 (and Pl14A) is rich in Polyplacognathus sp., and the faunas listed by Thompson (1959) in the shale horizon below the DKb match the faunas reported by Webers (1966) in terms of species (note that Thompson [1959, p. 67] thought Polyplacognathus was a synonym of Amorphognathus).

4. Samples P110/11, Pl12, and Pl13 are from the McGregor Member of the Platteville Formation. The McGregor Member underlies the Carimona Member of the Platteville Formation in Minnesota (Sloan, 1987; Webers, 1966). Thus, the samples from the McGregor Member all predate the DKb.

Replotting the data with correct position relative to the DKb (Fig. 1) shows that the evidence for cooling precedes the deposition of the bentonite. Therefore, the eruption could not have triggered cooling. In other

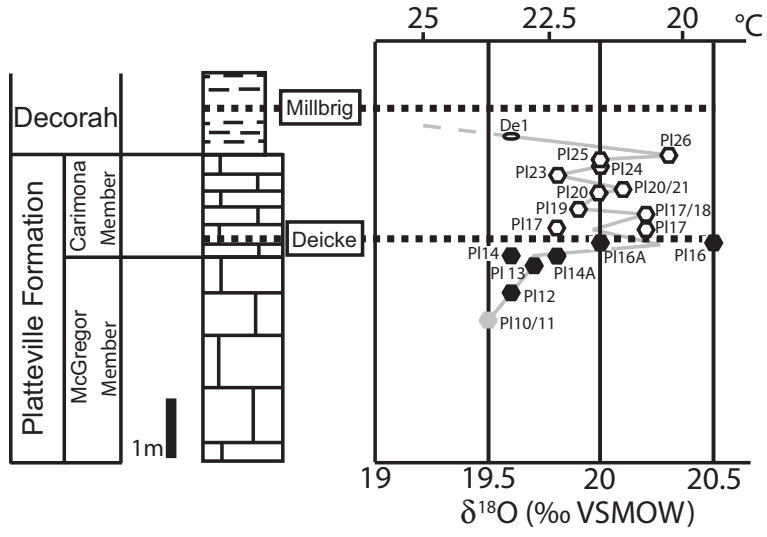

Figure 1. Plot of samples PI10/11 through De1 from Buggisch et al. (2010). PI samples are from the Cummingsville Annex Section; stratigraphy is from Webers (1966). Note that, using the correct placement of samples with regard to Deicke K-bentonite (DKb) bed, the cooling event occurred prior to the volcanic eruption. Black solid polygons are samples from below the DKb, black open polygons are samples above the DKb within the Carimona; oval is the first sample within the Decorah. Lowermost sample (gray polygon) reported in the supplementary data set of Buggisch et al. (2010, GSA Data Repository item 2010087) is PI10/11, but it apparently was not plotted in their figures. Additionally, this sample (PI10/11) is listed as $3.50 \mathrm{~m}$ in the supplementary data set, but according to the Webers (1966) stratigraphy, is at $\sim 6.46 \mathrm{~m}$.

words, the answer to the question "Did intense volcanism trigger the first Late Ordovician icehouse?," using the data set of Buggisch et al. (2010), seems to be "no." We have found the same pattern of apparent temperature change, i.e., cooling prior to the DKb, in the Sogn, Minnesota, section (Herrmann et al., 2010). Clearly, geographic coverage is still limited, but this agreement across studies argues that conodont paleothermometry will increasingly provide a valuable perspective on Paleozoic climate evolution.

\section{REFERENCES CITED}

Buggisch, W., Joachimski, M.M., Lehnert, O., Bergström, S.M., Repetski, J.E., and Webers, G.F., 2010, Did intense volcanism trigger the first Late Ordovician icehouse?: Geology, v. 38, p. 327-330, doi:10.1130/G30577.1.

Herrmann, A.D., MacLeod, K., and Leslie, S.A., 2010, Did a volcanic megaeruption cause global cooling during the Late Ordovician?: Palaios, v. 25, p. 831-836, doi:10.2110/palo.2010.p10-069r.

Leslie, S.A., 2000, Mohawkian (Upper Ordovician) conodonts of Eastern North America and Baltoscandia: Journal of Paleontology, v. 74, p. 1122-1147, doi:10.1666/0022-3360(2000)074<1122:MUOCOE>2.0.CO;2.

Leslie, S.A., 2009, Relationships between Upper Ordovician (Mohawkian) lithofacies and conodont biofacies distribution patterns using K-Bentonite beds as time-planes, eastern North America and northwestern Europe, in Over, D.J., ed., Conodont studies commemorating the 150th anniversary of the first conodont paper (Pander, 1856) and the 40th anniversary of the Pander Society: Palaeontographica Americana, p. 23-40.

Sloan, R.E., 1987, Tectonics, biostratigraphy and lithostraigraphy of the Middle and Late Ordovician lithostratigraphy and biostratigraphy of the upper Mississippi valley, in Sloan, R.E., ed., Middle and Late Ordovician lithostratigraphy and biostratigraphy of the Upper Mississippi Valley: Saint Paul, Minnesota, Minnesota Geological Survey Report of Investigations 35, p. 7-20.

Thompson, W.H., 1959, The conodonts of the Platteville Formation of southeastern Minnesota [unpublished M.S. thesis]: Minneapolis, Minnesota, University of Minnesota, $169 \mathrm{p}$.

Webers, G.F., 1966, The Middle and Upper Ordovician conodont faunas of Minnesota: Minnesota Geological Survey Special Publication Series 4, 123 p.

Weiss, M., 1955, Some Ordovician brachiopods from Minnesota and their stratigraphic relations: Journal of Paleontology, v. 29, p. 759-774. 